\title{
Development of Varroa jacobsoni in colonies of Apis mellifera iberica in a Mediterranean climate
}

\author{
Manuela R. Branco*, Neil A.C. Kidd, Robert S. Pickard \\ School of Pure and Applied Biology, University of Wales, \\ PO Box 915 Cardiff CFI 3TL, Wales, UK
}

(Received 17 December 1998; revised 26 May 1999; accepted 12 July 1999)

\begin{abstract}
Studies on Varroa jacobsoni population dynamics were conducted on 32 full-sized honeybee colonies of the Iberian bee race. The $V$. jacobsoni population growth followed an exponential model until it reached a collapse phase. In the experimental conditions this happened about 8 months to 1 year after chemical treatment. On average, the weekly intrinsic mite growth rates were very high, the yearly increases in mite population were 209 232-, $5436-, 942-$ (with drone baiting) and 3036 fold. A modelling approach was developed to describe the mite intrinsic growth rate regarding a) an overall range, b) only growth phenomena or c) only decay phenomena. The probability of cach mite finding a free larva on which to reproduce, the occurrence of mite immigration, and the mite death rate were the most significant variables to explain the mite intrinsic growth rate during the growth phase. The model had a good fit, $\mathrm{R}^{2}=0.905$, and good predictive performances, $\mathrm{R}_{\text {Prediction }}^{2}=0.896 . \odot$ Inra/DIB/AGIB/Elscvier, Paris
\end{abstract}

Varroa jacobsoni / Apis mellifera iberica / population growth / Mediterranean climate / statistical modelling

\section{INTRODUCTION}

Although efficacious acaricides have been developed to treat honeybee colonies against the parasitic mite Varroa jacobsoni, the generalised use of chemical products has well-known disadvantages. Thus, studies on the host-parasite population dynam- ics are important to analyse and develop adequate integrated control measures. In Mediterranean regions, the difficulties in controlling the mite are especially acute, since honeybee colonies exhibit brood rearing almost all year round, which is particularly favourable for $V$. jacobsoni population growth. In the present work, the develop-

\footnotetext{
* Correspondence and reprints: Instituto Superior de Agronomia, Departamento de Engenharia Florestal, Tapada da Ajuda, 1300 Lisboa, Portugal

E-mail: mrbranco@isa.utl.pt
} 
ment of the mite population was analysed in colonies of the Iberian bee (Apis mellifera iberica) in a Mediterranean climate.

Several authors have studied the reproductive behaviour and the population dynamics of the $V$. jacobsoni mite $[7,8,11$, $15,19,21,32]$. Several modelling works were also developed on varroa population dynamics, including discrete $[2,5]$ and continuous models $[6,9,22,25]$. These models were based on mathematical equations considering mite death and birth rates according to biological criteria. In the present work, a statistical modelling approach was used to analyse the host-parasite population interaction and to explain the variability of the mite intrinsic growth rate in relation to environmental and density-dependent variables. The aim was to gain a better understanding of the most important variables that influence the mite population growth rate and, whenever possible, to achieve a predictive statistical model.

\section{MATERIALS AND METHODS}

\subsection{Field methodology}

The experiments were carried out on 32 fullsized honeybee colonies of the Iberian bee race (A. m. iberica) from an apiary managed for commercial purposes. The beehives were 'Lusitana', a Portuguese model with $30 \times 33 \mathrm{~cm}$ frames in the brood chamber. The colonies were kept in honey production during the 3 years of experiments with an average productivity of $50 \mathrm{~kg}$ per colony per year. The apiary was located in agroforested land in Portugal $\left(38^{\circ} 42^{\prime} \mathrm{N}, 9^{\circ} 11^{\prime} \mathrm{W}\right)$. The monthly average temperatures ranged from $12{ }^{\circ} \mathrm{C}$, in the winter, to $23^{\circ} \mathrm{C}$ in summer.

Before the beginning of experiments all colonies were treated with fluvalinate (Apistan ${ }^{\text {(1) }}$ ) to homogenise the mite population at a low level. Apistan strips were applied for 6 weeks. The colonies were queen-right by July of 1993, with queens that were reared that season.

The first period of the mite population growth was observed from summer of 1993 until February 1994. By that time, only 24 colonies had low or moderate infestation levels. Twelve of these colonies were randomly selected and treated with Apistan, the other half of the colonies were not treated. Six of these colonies were further submitted to a biotechnical control method: the drone bait measure. The second period of the mite population growth was observed starting in April 1994 considering two groups of treated and nontreated colonies. All treated colonies were given a third Apistan treatment in December 1994. No mite resistance to Apistan was observed during the experiments. A third period of population growth was observed from February to November 1995 .

Data concerning several parametcrs of the honeybee colonies and the mite populations were periodically collected such as: a) immature bee numbers, $b$ ) adult bee numbers, $c$ ) mite natural mortality, and d) the number of mites killed by the chemical treatments, as described below.

a) The immature bee population of the colonies was observed every 2 weeks using video camera recording. A software image analyser (CUE-2, version 4.5, Galai Production Ltd) was used to estimate the sealed brood area. To convert the sealed worker brood area into a number of immature worker bees, the area of a fixed number of cells was measured. An average of 373 $( \pm 1.10 \mathrm{SE}, n=150)$ cells per $\mathrm{dm}^{2}$ was determined. Sealed drone cells were counted directly from the video images.

b) Adult bee populations were estimated, every month, comparing the frames covered with bees with calibrated photographs used as reference images. The frames were evaluated on both sides, and bees on the hive walls and bees working on the field were also counted.

c) The natural mortality of mites was recorded by means of a bottom board which consisted of a hive floor made from a $3-\mathrm{mm}$ wire mesh in a wooden frame with a tray under it acting as a removable drawer. A sheet of paper was placed inside the drawer and was replaced every week. This tray allowed collection of all the litter which fell to the bottom of the hive, free of propolis. Each sheet of paper was examined carefully in the laboratory and all the mites on it were separated and counted.

d) The absolute mite population was estimated by collecting and counting the dead mites over six consecutive weeks after acaricide treatments.

The taxonomic identification of the experimental honeybee colonies was verified by discriminant analysis using morphometric characteristics of adult bees [29]. 


\subsection{Statistical methodology}

To study the mite population growth in the individual colonies, the variable, net intrinsic growth rate, $r$, was selected and analysed based on the continuous form of the classic densityindependent population model [14]. The net growth rate was estimated on a weekly basis for each colony and each sub-period, so the notation, $r_{7}$, was used to specify a week's (7 days) growth rate. Sub-period is a division in time resulting from breaks in the mite population growth caused by the three chemical treatments or by events related to colony brood rearing, such as queen supersedure. A sub-period division according to season was also made. To estimate $r_{7}$, an exponential trendline was fitted to the data for the number of natural dead mites within the individual colony over the sub-period. The statistic $R^{2}$ was used to evaluate the quality of the fitted trendline. When $R^{2}$ was too small $(<0.75)$, which mainly happened in sub-periods which were too short or when the mite population was too small for a reliable trendline fitting, an alter- native method was used to estimate $r_{7}$. This alternative was based on estimates of the mite population at the initial $\left(V_{t i}\right)$ and linal points $\left(V_{t f}\right)$ of the period $(t f>t i)$, using the equation:

$$
r_{7}=\left(\log V_{t f}-\log V_{t i}\right) /(t f-t i)
$$

To model the net growth rate, $r_{7}$, several candidate explanatory variables related to the host and parasite populations were applied by multivariate regression analysis (table I). A backward stepwise regression method was used to withdraw the non-significant independent variables $\left(\mathrm{F}_{\text {axwithdraw }}=0.15\right)$. The statistical package Systat 5.0 for Windows was used.

The number of mites present in the colony at each observation time $(V)$ was estimated by a simulation method. First, the absolute mite population present at the end of the sub-period $\left(V_{t f}\right)$ was calculated from mite drop data at the time of Apistan treatments. Finally, the mites present in the colony were estimated every 2 weeks in a backward procedure simulating the estimated net growth rate, $r_{7}$, throughout the period of analysis (table II).

Table I. Explanatory variables used for the multivariate regression models.

\begin{tabular}{|c|c|}
\hline $\begin{array}{l}\text { Bees } \\
\text { Bv }\end{array}$ & $\begin{array}{l}\text { mean number of adult bees present in the colony } \\
\text { proportion of adult bees to mites. In broodright colonies it is considered that only } 36.84 \% \\
\text { of mites were infesting adult bees, hased on an average mite phoretic period of } 7 \text { days }\end{array}$ \\
\hline$W$ & mean number of immature worker bees present in the colony \\
\hline$W v$ & proportion of immature worker bees (in 10000 units) to mites \\
\hline$V$ & mean number of mites \\
\hline$D$ & mean number of immature sealed drones in the colony \\
\hline Dv & proportion of immature drones to mites \\
\hline$D w$ & proportion of immature drones to immature worker bees \\
\hline$D p$ & $\begin{array}{l}\text { percentage of potential varroa reproducing on drones. A preference ratio of the mite } \\
\text { for drone larvae of } 8: 1 \text { was considered }\end{array}$ \\
\hline$P_{\text {hees }}$ & $\begin{array}{l}\text { probability, assuming a Poisson distribution, of an adult bee being infested by none or } \\
\text { just one mite }\left(P_{\text {larvice }}=\mathrm{e}^{-}(1 / \mathrm{wr})(1+(1 / W v))\right)\end{array}$ \\
\hline$P_{\text {lirrvae }}$ & $\begin{array}{l}\text { probability, assuming a Poisson distribution, of an immature worker bee being } \\
\text { infested by none or just one female mite }\left(P_{b c c x}=\mathrm{e}-\left(1 / h^{(1)}\right)(1+(1 / B v))\right)\end{array}$ \\
\hline$D_{\text {ratle }}$ & $\begin{array}{l}\text { mean mite death rate. Ratio between the mites dying weekly and the population of } \\
\text { mites estimated to be present in the colony }\end{array}$ \\
\hline $\ln v$ & $\begin{array}{l}\text { categorical variable, with two levels, expressing if a colony has being submitted to a } \\
\text { strong mite invasion related to robbing activity }\end{array}$ \\
\hline$D_{\text {rif }}$ & $\begin{array}{l}\text { categorical variable with two levels. The level one stands for colonies susceptible to a } \\
\text { small but systematic mite invasion due to drifting bees }\end{array}$ \\
\hline Season & categorical variable with four levels to assess seasonal variability \\
\hline Temp & average daily temperature \\
\hline
\end{tabular}


Table II. Simulation of the mite population growth (colony 36, from May to November 1994).

\begin{tabular}{|c|c|c|c|c|c|c|c|c|c|}
\hline Date & $\begin{array}{l}V \\
\text { (mites } \\
\text { estim.) }\end{array}$ & $W$ & $W_{v}$ & $D$ & $D w$ & $D v$ & $P_{\text {larvac }}$ & $\begin{array}{l}\text { Mite } \\
\text { drop } \\
\text { data }\end{array}$ & $D_{\text {rate }}$ \\
\hline $18 / 05$ & 32 & 12179 & 386.5 & 37 & 0.003 & 1.174 & 1 & 2 & 0.048 \\
\hline $1 / 06$ & 47 & 12550 & 269.2 & 70 & 0.006 & 1.501 & 1 & 7 & 0.157 \\
\hline $15 / 06$ & 69 & 14061 & 203.8 & 138 & 0.01 & 2 & 1 & 5 & 0.072 \\
\hline $29 / 06$ & 102 & 12122 & 118.7 & 60 & 0.005 & 0.588 & 1 & 6 & 0.054 \\
\hline $13 / 07$ & 151 & 10627 & 70.36 & 517 & 0.049 & 3.423 & 1 & 9 & 0.056 \\
\hline $27 / 07$ & 223 & 7849 & 35.12 & 84 & 0.011 & 0.376 & 1 & 8 & 0.034 \\
\hline $10 / 08$ & 331 & 5746 & 17.38 & 247 & 0.043 & 0.747 & 0.999 & 17 & 0.05 \\
\hline $24 / 08$ & 489 & 6173 & 12.62 & 139 & 0.023 & 0.284 & 0.998 & 12 & 0.025 \\
\hline $6 / 09$ & 724 & 6515 & 8.999 & 156 & 0.024 & 0.215 & 0.996 & 32 & 0.044 \\
\hline $21 / 09$ & 1071 & 6573 & 6.136 & 92 & 0.014 & 0.086 & 0.99 & 87 & 0.081 \\
\hline $6 / 10$ & 1585 & 6588 & 4.156 & 58 & 0.009 & 0.037 & 0.978 & 125 & 0.079 \\
\hline $19 / 10$ & 2345 & 7793 & 3.323 & 109 & 0.014 & 0.046 & 0.969 & 133 & 0.057 \\
\hline $3 / 11$ & 3470 & 7224 & 2.082 & 5 & $7 \mathrm{E}-04$ & 0.001 & 0.916 & 199 & 0.057 \\
\hline $16 / 11$ & 5135 & 6486 & 1.263 & 2 & $3 \mathrm{E}-04$ & $4 \mathrm{E}-04$ & 0.812 & 307 & 0.06 \\
\hline $24 / 11$ & 6246 & & & & & & & & \\
\hline Mean & 1127 & 8749 & 81.4 & 122 & 0.015 & 0.749 & 0.976 & & 0.063 \\
\hline
\end{tabular}

Estimated $r_{7}=0.1959, \mathrm{R}^{2}=0.9153$.

Number of mites killed at the end of the period by chemical trealment $=6246$.

Other variables: $D p=5.244 ;$ Bees $=17.476 ; B v=42.099 ; P_{\text {bees }}=0.9997$.

Residual analysis was performed to diagnose the normality and independence assumptions for each model. Several statistics, both of fitting and predictive ability, were also estimated as $\mathrm{R}^{2}$, adj $\mathrm{R}^{2}$, MSE, PRESS and $\mathrm{R}_{\text {Prediction }}^{2}$ [23]. The correlation matrix of parameters was analysed for the diagnosis of the multicolinearity in the regressor variables.

\section{RESULTS}

Two kinds of models were fitted to the data: a) average growth model and b) individual colony growth model. The average growth model was applied to the mean values. This model describes the average mite population growth for the whole apiary but does not take into account the variability observed between colonies, which was analysed by the individual colony growth model.

\subsection{Average growth model}

In all experimental periods, independently of season, an exponential growth curve of the mite population was observed (figure 1). The mite population growth observed all year round was explained by the continuous presence of brood in the colonies.

By the end of the summer of 1994, the group of colonies not treated with fluvalinate reached very high infestation levels. According to the host and parasite population dynamics, the period observed was divided into two phases: a growing phase, characterised by an exponential growth of the mite population, followed by a collapse phase, where a breakdown in both bee and mite populations was suddenly observed (figure $1 c$ ). In the experimental conditions, a colony collapse happened approximately 8 months 


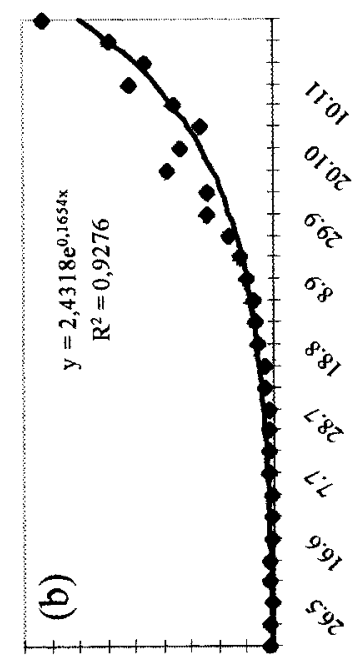

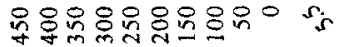

səł!̣u pвәр КГҮәәМ

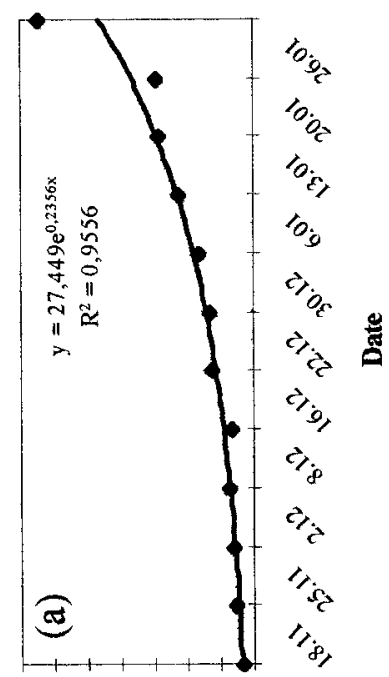

융융유융잉

səụu prop КруәәМ

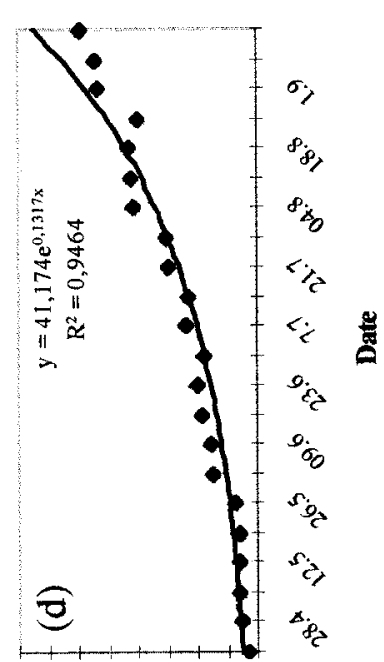

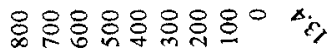

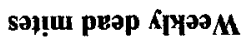

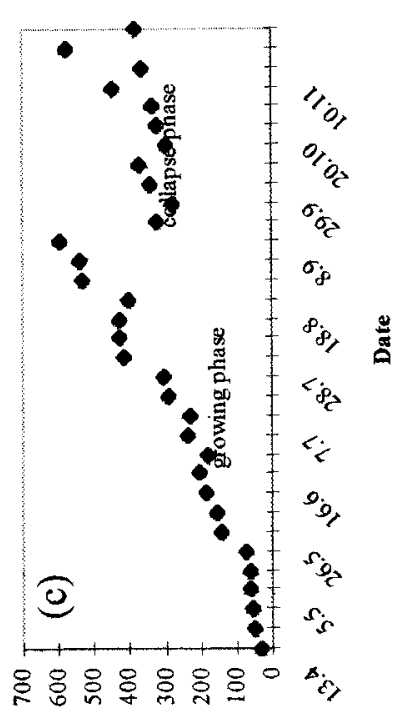

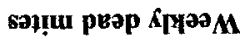

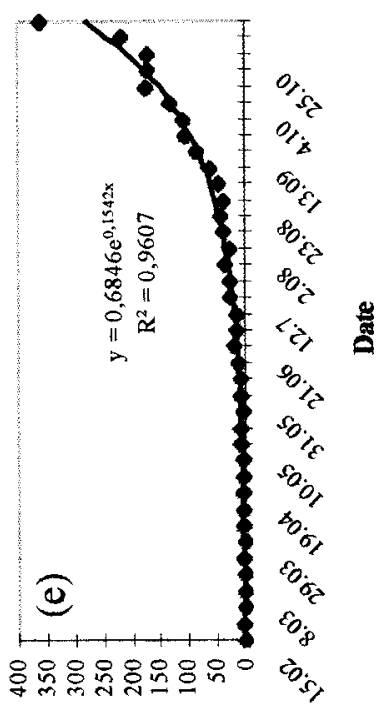

sə!!u реәр КүуәәМ

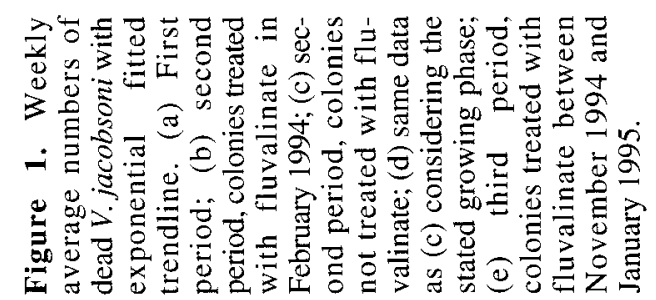


to 1 year after the chemical treatment.

A rate of population increase per unit of time, $R$, can also be defined:

$$
R=\mathrm{e}^{r}=N_{l} / N_{t-l}
$$

where $N_{t}$ is the number of individuals at $t$ and $r$ is the net growth rate.

An average weekly intrinsic rate of population increase of $R_{7}=1.27,1.18,1.14$ and 1.17 was observed for the first period, second period non-treated colonies, second period treated colonies and third period, respectively. Given these rates of increase, the mite population would increase within a year 209 232-, 5 436-, 942- and 3 036-fold, respectively. The net growth rate found for the first period was particularly high, $r_{7}=0.236$. The result is in part explained by a low mite death rate observed in a group of colonies. The lowest value was found in the second period in the colonies not treated with fluvalinate $\left(r_{7}=0.132\right)$, which was influenced by the drone bait method applied to a group of colonies during this period.

\subsection{Individual colony growth model}

One hundred and fourteen values of $r_{7}$ were estimated from the individual colonies in several sub-periods. Data comprised positive values for sub-periods with mite population growth (92 cases) and negative values ( 22 cases) concerning sub-periods of mite population decay.

The Pearson correlation shows that the variables, $P_{\text {larvae }}$ and $P_{\text {bces }}$, were the most correlated with $r_{7}(\mathrm{r}=0.883$ and 0.733 , respectively). The variable $P_{\text {larvae, the prob- }}$ ability of a larva being infested by just one or no female mites, more adequately described the data than the absolute or relative numbers of larvae available. In fact, for a low mite infestation, the magnitude of the host population was irrelevant, the female mites always had a high probability (near one) of finding a free larva on which to reproduce. The variable, $P_{\text {bees }}$, may have a similar biological interpretation. If the phoretic mite number is greater than the adult bee population, an increase in the mite death rate as well as a decrease in birth rate is expected owing to a greater difficulty for the mite in finding an appropriate host or having a poor diet during the phoretic stage.

\subsubsection{Analysis of the overall range of values}

The overall data encompassed a very wide range of situations, from severely infested and broodless colonies, where the mite population exhibited decay, to the highest positive net growth rates. To model the overall range of $r_{7}$ the variables $P_{\text {larvae }}, P_{\text {bees, }}$, mite immigration by robbing (Inv) and the ratio of immature worker bees to mites $\left(W_{v}\right)$ were selected by the backward stepwise procedure (table III). The model had a good fit $\left(R^{2}=0.967\right)$ and good predictive qualities $\left(\mathrm{R}_{\text {Prediction }}^{2}=0.965\right)$. The model $\cdot$ was valuable for its description of the variable $r_{7}$ throughout a very large range of values. Because of its wide range, however, it also lacked accuracy when the object of analysis was concentrated only on positive or negative values.

\subsubsection{Analysis of the positive values}

The positive values of $r_{7}$ included a data set with 92 cases, mean $0.190( \pm 0.005 \mathrm{SE})$, minimum 0.053 and maximum 0.325 . To explain this data set the variables $P_{\text {larvae, }}$ $D_{\text {rate }}, \operatorname{In} v, D_{\text {rift }}$ and $W v$ were significant (table III). The model has a good fit $\left(\mathrm{R}^{2}=0.905\right)$ and reliable predictive qualities $\left(\mathrm{R}_{\text {Prediction }}^{2}=0.896\right)$.

The variable $P_{\text {larvac }}$ explains a densitydependent effect. For this data set, $P_{\text {bces }}$ and $P_{\text {larvae }}$ were significantly correlated $(\mathrm{r}=0.840)$, so a model that includes them both is overparameterised.

The mean value observed for the variable death rate $\left(D_{\text {rate }}\right)$ was $0.090( \pm 0.001$ $\mathrm{SE})$. Logically, colonies where mites have higher death rates should exhibit lower growth rates, which is expressed by the neg- 
Table III. Estimated coefficients, $\mathrm{R}^{2}$ and $\mathrm{R}_{\text {Prediction }}^{2}$ of the selected models.

\begin{tabular}{|c|c|c|c|c|}
\hline Models & $\begin{array}{l}\text { Coefficie } \\
( \pm \text { SE) }\end{array}$ & & $\begin{array}{l}\mathrm{R}^{2} \\
\mathrm{R}_{\text {Prediction }}^{2}\end{array}$ & $\begin{array}{l}\text { Variables dropped } \\
\text { out }\end{array}$ \\
\hline Overall range of $r_{7}$ & $\begin{array}{l}\text { constant } \\
P_{\text {bees }} \\
P_{\text {larvae }} \\
\operatorname{Inv} \\
W v\end{array}$ & $\begin{array}{l}=-1.389( \pm 0.064) \\
=1.305( \pm 0.068) \\
=0.267( \pm 0.008) \\
=0.143( \pm 0.010) \\
=0.004( \pm 0.001)\end{array}$ & $\begin{array}{l}0.967 \\
0.965\end{array}$ & $\begin{array}{l}\text { Bees, } B v, D p, D v \\
D w, D_{\text {rif }}, V, W \\
\text { Temp, Season }\end{array}$ \\
\hline Positive values of $r_{7}$ & $\begin{array}{l}\text { constant } \\
P_{\text {larvae }} \\
D_{\text {rate }} \\
\text { Inv } \\
D_{\text {rif }} \\
W v\end{array}$ & $\begin{array}{l}=-0.025( \pm 0.033) \\
=0.288( \pm 0.035) \\
=-0.939( \pm 0.049) \\
=0.131( \pm 0.006) \\
=0.039( \pm 0.006) \\
=0.003( \pm 0.001)\end{array}$ & $\begin{array}{l}0.905 \\
0.896\end{array}$ & $\begin{array}{l}\text { Bees, Bv,Dp,Dv, } \\
D w, V, W, P_{\text {bees }} \\
\text { Temp, Season }\end{array}$ \\
\hline $\begin{array}{l}\text { Positive values of } r_{7} \\
W v \text { is replaced by } D v\end{array}$ & $\begin{array}{l}\text { constant } \\
P_{\text {laryae }} \\
D_{\text {rate }} \\
I n v \\
D_{\text {rif }} \\
D v\end{array}$ & $\begin{array}{l}=-0.034( \pm 0.033) \\
=0.298( \pm 0.035) \\
=-0.944( \pm 0.050) \\
=0.131( \pm 0.006) \\
=0.038( \pm 0.006) \\
=0.001( \pm 0.000)\end{array}$ & $\begin{array}{l}0.902 \\
0.896\end{array}$ & $\begin{array}{l}\text { Bees, } B v, D p, D w \\
V, W, W v, P_{\text {bees}} \\
\text { Temp, Season }\end{array}$ \\
\hline Negative values of $r_{7}$ & $\begin{array}{l}\text { constant } \\
P_{\text {larvae }} \\
P_{\text {bees }} \\
V\end{array}$ & $\begin{array}{l}=-1.504( \pm 0.047) \\
=0.215( \pm 0.039) \\
=1.417( \pm 0.048) \\
=0.003( \pm 0.001)\end{array}$ & $\begin{array}{l}0.986 \\
0.969\end{array}$ & $\begin{array}{l}\text { Bees, Bees, Bv, } \\
\text { Dp, Dv, W, Wv, Dw, } \\
\text { Temp, Season }\end{array}$ \\
\hline
\end{tabular}

ative coefficient regression of the variable, $D_{\text {rate }}(-0.939)$. This coefficient was almost -1 , which indicated that the variable almost overlayed the real mite death rate. $D_{\text {rate }}$ was not significantly correlated with either of the remaining regressor variables, so differences observed in the mite death rate must have been related to other factors rather than to the mite or to the host population densities. An intra-racial genetic variability may explain the large differences observed among colonies. This hypothesis agrees with the fact that colonies tend to maintain nearly the same level of mite death rate from one period to another, with the exception of when queen supersedure occurred.

$\operatorname{Inv}$ and $D_{\text {rif }}$ are two categorical variables with two levels each ( 1 and 0 ) expressing either a colony submitted to a mite invasion or not. The variable Inv expresses a punctual but strong mite invasion due to robbing against colonies dying from varroasis. This event was detected in ten cases by a sudden peak in the number of natural dead mites found on the floor-traps associated with the presence of a highly infested colony nearby. The variable $D_{\text {rif }}$ expresses a more continuous but weak mite immigration. Level 1 represents colonies placed next to highly infested colonies and so were susceptible to a small but systematic mite invasion due to drifting bees (eight cases). In one case, both events were observed (table IV).

The regression model clearly shows the importance of these events. The mite net growth rate was 0.131 times higher in 
Table IV. Net growth rate, $r_{7}$, (mean $\pm \mathrm{SE}$ ) observed for the mite population according to levels of the variables $I n v$ and $D_{\text {rif }}$.

\begin{tabular}{ccc}
\hline & $\ln v=0$ & $\operatorname{Inv=1}$ \\
\hline$D_{\text {rif }}=0$ & $\begin{array}{c}0.178 \pm 0.004 \\
(n=75)\end{array}$ & $0.277 \pm 0.019$ \\
$D_{\text {rif }}=1$ & $\begin{array}{c}0.191 \pm 0.014 \\
(n=7)\end{array}$ & 0.311 \\
& $(n=1)$ \\
\hline
\end{tabular}

colonies with mite immigration owing to the robbing of infested colonies than in colonies with no such activity. The effect of invasion due to drifting was lower but still important (0.039).

The mean number of immature worker bees per mite $(W v)$ was the least important regressor variable and had less visible biological meaning. In a first approach, it would seem that the variable, $P_{\text {larvae, }}$, would replace the variable $W v$. The absolute absence of any variable related to immature drone numbers was also surprising, since the reproduction rate of the female mites is higher in drone cells than in worker cells. These two puzzling observations are linked. The variable, $W v$, was highly correlated with the mean number of immature drones per mite $(D v), r=0.943$. A quite similar model was reached when the variable $D v$ replaced the variable $W v$. Although the model had a slightly poor fit performance $\left(\mathrm{R}^{2}=0.902\right)$, its predictive quality was equal to the former one. We may conclude that the number of immature drones reared by the colonies had an influence over the mite net growth rate, expressed by the variable, $D v$.

The model explained $90.5 \%$ of the variability in the raw data. Although this value may be considered high, $9.5 \%$ of variability was not explained. Since the variable, $D_{\text {rate}}$, reflected the real mite death rate well, the remainder of the regressor variables must explain birth or immigration rate. It is also reasonable to assume that the variability not explained by the model was also related to these factors. A genetic variability may pre- sumably explain differences in the mite birth rate observed amongst colonies. To study this hypothesis, a GLM was applied, using the former quantitative variables as covariates, and adding the colony factor $(\mathrm{Col})$. With this model the factor $C o l$ was significant $(P=0.030)$. Also, the percentage of variability explained by the model increased to $95.1 \%$. Thus, variability among colonies not related to the host and mite density was responsible in part for the mite birth rate variability.

The variables related to environmental and seasonal factors were omitted from the analysis. None of these variables seemed to influence either mite growth rate or death rate $(P>0.05)$.

\subsubsection{Analysis of the negative values}

The negative values of $r_{7}$ had a mean of $-0.151( \pm 0.025 \mathrm{SE}, n=22)$, ranging from -0.48 to -0.06 . This data set coincided with a wide variety of situations including broodless colonies, with very low to extreme mite infestation levels, as well as broodright colonies severely affected by varroasis. In broodless colonies, the mite birth rate was nil and thus the negative growth rate coincided with the death rate. In broodless colonies with low infestation levels the variability observed was low, $r_{7}=-0.087$ $( \pm 0.005 \mathrm{SE}, n=10)$. This value is most similar to the variable death rate estimated for the analysis of the positive intrinsic growth rates $\left(D_{\text {rate }}=0.09\right)$. Colonies with brood but so severely infested that the mite death rate was greater than its birth rate correspond to a collapse phase, which never lasts longer than a few weeks.

To model the negative values, the variables $P_{\text {bees }}, P_{\text {larvac }}$ and the mite population, $V$, were selected (table III). The variable $P_{\text {bees }}$ alone explained $92.8 \%$ of the variability in the data. This variable was needed to discriminate mite population decay in cases with negative $r_{7}$ and with no brood. This means that the probability of a mite finding a bee not yet infested increased its 
survival in a broodless or highly infested colony. The variable $P_{\text {larvae }}$ was needed to discriminate the situations comprising severely infested broodright colonies. The mite population $(V)$ was the less significant variable $(P=0.004)$. This variable expressed an effect of mite density on its death rate. This effect was already accessed by the variables, $P_{\text {bees }}$ and $P_{\text {larvae, }}$, in relation to the host adult and immature populations, respectively.

The fit and predictive qualities of the regression model for the negative net growth rate were very high $\left(R^{2}=0.986\right.$; $\mathrm{R}_{\text {prediction }}^{2}=0.969$ ).

\section{DISCUSSION}

The varroa population growth behaved as an exponential model until it reached a collapse phase when host and parasite populations suffered a rapid decline, which agrees with several other published studies $[2,6,9,25]$. However, different growth rates are reported according to bee race and geographical location [24, 26, 28, 33].

The mite population growth was observed all year round, owing to the continuous presence of brood. This effect differed from results observed in temperate climates, where the mite population suffered winter losses and a breakdown $[8,17]$. Thus, in our experimental conditions, colony collapse could happen from 8 months to 1 year after treatment.

On average, the weekly rates of population increase observed were high, $R_{7}=1.27$, $1.18,1.14$ and 1.17. The lowest value is for a situation where the rate of increase was lowered owing to the use of a biotechnical control method. These results tend to be larger than those reported for other European regions at the spring/summer time. Guermant et al. [13] reported for north-east Italy an average increase of 4-fold within 70 days, which corresponded to 1.15 as a weekly rate of increase. Korpela et al. [17] found in south-east Finland a mite popula- tion increase from 25.7 to 85.8 mites per day, over 2 months, which also gives $R_{7}=1.15$. Kraus and Page $\mathrm{Jr}$ [18] found $R_{7}$ varying from 1.10 to 1.16 in California, USA. The higher values observed in the present study may be in part a result of characteristics of the Iberian bee which are particularly favourable for the mite population growth. Also, Calatayud and Verdu [3, 4] measured the daily increase of mites on Iberian bee colonies and found the growth rate to be 0.027 and 0.021 per day, that is $R_{7}=1.21$ and 1.16 , respectively. The first value is closer to our results. Furthermore, these experiments were conducted during autumn in the absence of drone brood with a reduced possibility of migration of parasites. Our data comprises 3 years of experiments including periods of high drone brood rearing and mite migration, which justifies on average a considerable mite population increase.

The mite net growth rate $\left(r_{7}\right)$ varied greatly among individual colonies. A statistical modelling approach was used to explain this variability. According to the selected models, the main factors affecting the mite population growth were related to the probability of finding a free host, expressed by the variable $P_{\text {larvae }}$, mite migration fluxes caused by drifting and robbing, and the mite death rate. The variable $P_{\text {larvac }}$ explained a density-dependent effect caused by the multiple infestation of the cells [7, 12]. The importance of invading mites by drifting and robbing activity has been documented in several reports $[16,27,31]$. This work confirms the importance of these activities. The mite death rate $\left(D_{\text {rate }}\right)$ was one of the most important selected variables for modelling the positive values of $r_{7}$. The mean value observed was 0.090 , but ranged from 0.032 to 0.281 . The higher values corresponded to a colony with a weekly mite growth rate of 0.157 and 0.135 on the first and second sub-periods while the average values were 0.236 and 0.165 , respectively. Honeybee genetic variability related to mite death rate and tolerance to $V$.jacobsoni has 
been the subject of study by several researchers $[1,10,24,30,33]$. In view of the present study, it may be that intra-racial genetic variability could also be responsible for differences among colonies of the same race.

The number of immature drones reared by the colonies also had an influence over $r_{7}$, given by the variable $D v$ which is understandable since the reproduction rate of female mites is higher in drone cells than in worker cells $[12,15,32]$.

The environmental variables had no significant influence on $r_{7}$. This result does not agree with other studies that report seasonal variance in the mite reproduction and population growth $[19,20]$. The present result may be explained by the characteristic Mediterranean weather.

The weekly mortality rate of mites observed in broodless colonies (0.087) and in colonies with brood rearing (0.09) was consistent with a stated mite summer longevity of approximately $72-75$ days, or a daily mortality rate of $0.013[6,25]$. However, this value is substantially higher than the value used in other models $[9,22]$.

\section{ACKNOWLEDGEMENTS}

We thank National Forestry Station, INIA, for the use of the apiary, and to the Forest Technology Sector of the ISA for the use of the software image analyser. M. Branco wishes to acknowledge the support of the British Council for a studentship and expresses her thanks to Professor Francisco Rego for help and advice.

Résumé - Développement de Varroa jacobsoni dans les colonies d'Apis mellifera iberica en climat méditerranéen. La dynamique des populations de Varroa jacobsoni Oudemans a été étudiée sur 32 colonies d'Apis mellifera iberica Goetze en climat méditerranéen durant trois années. Toutes les colonies avaient été traitée au fluvalinate (Apistan ${ }^{\circledR}$ ) avant le début de l'expérience. Les données suivantes ont été relevées périodiquement : nombre d'abeilles immatures et d'abeilles adultes, mortalité naturelle de $V$. jacobsoni et nombre d'acariens tués par les traitements chimiques.

Pour étudier la croissance des populations de $V$. jacobsoni dans des colonies d'abeilles, on a estimé le taux de croissance hebdomadaire pour chaque colonie et chaque souspériode $r_{7}$. On a obtenu 114 valeurs de $r_{7}$, certaines positives, correspondant aux périodes de croissance, d'autres négatives, correspondant aux périodes d'effondrement de la population de $V$. jacobsoni, qui ont été observées dans des colonies sans couvain ou ayant un niveau d'infestation très élevé. On a développé une approche par modélisation pour décrire le taux intrinsèque de croissance de l'acarien i) en général, ii) durant les seules périodes de croissance et iii) durant les seules périodes de déclin. L'analyse de régression multivariée a porté sur plusieurs variables explicatives possibles en relation avec les populations d'hôtes et de parasites (tableaux I et II). Une méthode de régression pas à pas a été utilisée pour retirer les variables indépendantes non significatives.

Dans toutes les expériences la population de $V$. jacobsoni a présenté une courbe de croissance exponentielle, ce qui s'explique par la présence continue de couvain (figure 1). A la phase de croissance succède une phase d'effondrement de la colonie qui, dans nos conditions expérimentales, est survenue entre huit mois et un an après le traitement chimique. On a observé un taux intrinsèque moyen hebdomadaire de l'accroissement de la population $\left(R_{7}\right)$ de $1,27,1,18$, 1,14 et 1,17 . Le plus petit chiffre correspond à une situation où le taux de croissance est abaissé par l'utilisation de méthodes de lutte biotechnique. Les chiffres obtenus sont plutôt au-dessus de ceux mentionnés dans d'autres travaux $[3,4,13,17,18]$. La probabilité pour chaque acarien de trouver une larve disponible pour se reproduire, l'existence d'une immigration de $V$. jacobsoni, due à la dérive et au pillage, et le taux de 
mortalité de l'acarien sont les variables les plus significatives pour expliquer le taux intrinsèque de croissance durant la phase de croissance. Le modèle a une bonne adéquation avec les données et de bonnes performances de prédiction (tableau III). La sélection dans le modèle des variables rendant compte de l'immigration de $V$. jacobsoni confirme l'importance de ce problème (tableau IV) [16, 27, 31]. Le taux de mortalité de l'acarien est l'une des variables sélectionnées les plus importantes pour expliquer $r_{7}$. Les facteurs génétiques intra-raciaux pouvant être impliqués, ceci pourrait être un bon critère de sélection pour la tolérance à $V$. jacobsoni. Contrairement à d'autres travaux $[19,20]$, nous n'avons observé aucune influence de la saison sur le taux de croissance intrinsèque de l'acarien. (C) Inra/DIB/ AGIB/Elsevier, Paris

\section{Varroa jacobsoni / Apis mellifera iberica / croissance population / climat méditer- ranéen / modélisation statistique}

\section{Zusammenfassung - Entwicklung von Varroa jacobsoni in Völkern von Apis mel- lifera iberica unter mediterranem Klima.}

Die Populationsentwicklung von Varroa jacobsoni wurde über 3 Jahre an 32 normal grossen Bienenvölkern von Apis mellifera iberica unter mediterranen Klimabedingungen untersucht. Hierbei wurden in regelmässigen Abständen Daten über verschiedene Aspekte der Bienenvölker und der Milbenpopulation wie z.B. Brutmenge, Anzahl der adulten Bienen, natürliche Milbensterblichkeit und die Anzahl der durch chemische Behandlung gestorbene Milben gesammelt. In allen experimentellen Zeiträumen konnte eine exponentielle Wachstumskurve der Milbenpopulation beobachtet werden, diese wird durch das ständige Vorhandensein von Brut in den Völkern erklärt (Abbildung 1). Unter den Versuchsbedingungen brachen die Völker Monate bis zu einem Jahr nach der chemischen Behandlung zusammen.
Die durchschnittliche intrinsische Rate der Populationszunahme betrug wöchentlich $R_{7}=1,27 / 1,18 / 1,14 /$ und 1,17. Der niedrigste Wert ergab sich, wenn die Zunahme durch biotechnische Bekämpfungsmethoden verringert wurde. Insgesamt waren in unseren Ergebnisse die Werte tendenziell höher als die in anderen Arbeiten angegebenen $[3,4,13,17,18]$.

Um das Wachstum der Milbenpopulation an einzelnen Völkern zu bestimmen, wurde die unterschiedliche wöchentliche Wachstumsrate für jedes Volk und jede Unterperiode bestimmt $\left(r_{7}\right)$. Die Daten umfassen 114 Werte von $r_{7}$. Diese waren teils positiv in der Wachstumszeit und teils negativ in den Perioden der Abnahme der Milbenpopulation, wie sie bei Völkern ohne Brut oder mit einem sehr hohen Befallsniveau auftrat. Ein Näherungsmodell für ein spezielles Milbenwachstum wurde für folgende Fälle entwickelt: a) für einen alles umfassenden Bereich, b) nur für die Wachstumsphänomene oder c) für die Abnahmephänomene. Mehrere mögliche Erklärungsvariablen, die mit Wirt und Parasitpopulationen zusammenhängen, wurde in einer multivaraten Regressionsanalyse untersucht (Tabellen $I$ und $I I$ ), hierbei wurden nicht signifikante unabhängige Variablen schrittweise rückwärts ausgeschlossen. Die bedeutendsten Variablen zur Erklärung der intrinsischen Wachstumsrate während der Wachstumsphase waren die Wahrscheinlichkeit einer einzelnen Varroamilbe eine freie Larve für die Reproduktion zu finden, die auf Verflug oder Ausräuberung zurückzuführende Milbenzuwanderung und die Todesrate der Milben. Das Modell hat gut angepasste Eigenschaften, die auch Vorhersagen erlauben (Tabelle III). Die Wahrscheinlichkeit für die Milbenweibchen eine freie Larve zu finden, erklärt den durch Mehrfachbefall einer Zelle hervorgerufenen dichteabhängigen Effekt und stimmt mit anderen Arbeiten überein [7, 12]. Die Auswahl von Variablen im Modell, die für die Milbeneinwanderung verantwortlich sind, bestätigt die Bedeutung dieses Problems (Tabelle IV) [16, 27, 31]. 
Die Todesrate der Milben war eine der bedeutendsten der ausgewählten Variablen zur Erklärung von $r_{7}$. Unter Berücksichtigung der möglichen Beteiligung von genetischen Faktoren innerhalb der Rasse könnte dies ein gutes Selektionskriterium für Varroateleranz sein. Im Gegensatz zu anderen Arbeiten $[12,19]$, wurde kein saisonaler Einflu $\beta$ auf die intrinsische Wachstumsrate beobachtet. (C) Inra/DIB/AGIB/Elsevier, Paris

\section{Varroa jacobsoni/Apis mellifera iberica / Populationswachstum / mediterranes Klima / statistisches Modell}

\section{REFERENCES}

[1] Boecking O., Drescher W., The reaction of worker bees in different Apis mellifera colonies to Varroa infested brood cells, in: Ritter W. (Ed.), Proceedings of the International Symposium on Recent Research on Bee Pathology, 5-7 September 1990, Ghent, Belgium, Merelbeke, Belgium, 1990, pp. 41-42.

[2] Bögel R., Folgerungen aus Modellrechnungen zum Vermehrungsverhalten von Varroa jacobsoni bei Wirtschaftsvölkern, Allg. Dtsch. Imkerztg. 19 (1985) 165-171.

[3] Calatayud F., Verdu M.J., Hive debris counts in honeybee colonies: a method to estimate the size of small populations and rate of growth of the mite Varroa jacobsoni Oud. (Mesostigmata: Varroidae), Exp. Appl. Acarol. 17 (1993) 889-894.

[4] Calatayud F., Verdu M.J., Number of adult female mites Varroa jacobsoni Oud. on hive debris from honeybee colonies artificially infested to monitor mite population increase (Mesostigmata: Varroidae), Exp. Appl. Acarol. 19 (1995) 181-188.

[5] Dinar A., Efrat C., Economic threshold for a pathogenic disease: the case of Varroasis in bees, Agric. Syst. 32 (1990) 13-25.

[6] Dolejsky W., Schley P., Ein mathematisches Simulationsmodell zur Äbschätzung der Population-sentwicklung im Bienenvolk (Apis mellifera L.) nach Befall mit der Milbe Varroa jacobsoni Oud., Zentralbl. Veterinärmed. 27 (1980) 798-805.

[7] Donze G., Herrmann M., Bachofen B., Guerin P.M., Effect of mating frequency and brood cell infestation rate on the reproductive sucess of the honeybee parasite Varroa jacobsoni, Ecol. Entomol. 21 (1996) 17-26.
[8] Fries I., Aarhus A., Hansen H., Korpela S., Development of early infestations by the mite Varroa jacobsoni in honey-bee (Apis mellifera) colonies in cold climates, Exp. Appl. Acarol. 11 (1991) 205-214.

[9] Fries I., Camazine S., Sneyd J., Population dynamics of Varroa jacobsoni: a model and a review, Bee World 75 (1994) 5-28.

[10] Fries I., Huazhen W., Wei S., Jin C., Grooming behavior and damaged mites (Varroa jacobsoni) in Apis cerana and Apis mellifera ligustica, Apidologie 27 (1996) 3-11.

[11] Fuchs S., Choice in Varroa jacobsoni Oud. between honeybee drone or workerbrood cells for reproduction, Behav. Ecol. Sociobiol. 31 (1992) 429-435.

[12] Fuchs S., Langenbach K., Multiple infestation of Apis mellifera $\mathrm{L}$. brood cells and reproduction in Varroa jacobsoni Oud, Apidologie 20 (1989) 257-266.

[13] Guermant C., Tursch B., Barbattini R., Chiesa F., D’Agaro M., Havoux J.C., Velocità di crescita dell'infestazione da Varroa jacobsoni Oud. nelle colonie di Apis mellifera L., Apic. Mod. 81 (1990) 157-165.

[14] Haefner J.W., Modeling Biological Systems. Principles and Applications, Chapman \& Hall, New York, 1996.

[15] Ifantidis M.D., Ontogenesis of the mite Varroa jacobsoni in worker and drone honeybee cells, J. Apic. Res. 22 (1983) 200-206.

[16] Imdorf A., Kilchenmann V., La réinvasion de Varroas : une mauvaise surprise pour l'apiculteur, J. Suisse Apic. 88 (1991) 106-111.

[17] Korpela S., Aarhus A., Fries I., Hansen H., Varroa jacobsoni Oud. in cold climates: population growth, winter mortality and influence on the survival of honeybee colonies, J. Apic. Res. 31 (1992) 157-163.

[18] Kraus B., Page Jr R.E., Population growth of Varroa jacobsoni Oud. in Mediterranean climates of California, Apidologie 26 (1995) 149-157.

[19] Kulincevic J.M., Rinderer T.E., Urosevic D.J., Seasonality and colony variation of reproduction and non-reproduction Varroa jacobsoni females in western honeybee (Apis mellifera) worker brood, Apidologie 19 (1988) 173-180.

[20] Marcangeli J., Eguaras M., Fernández N., Reproduction of Varroa jacobsoni (Acari: Mesostigmata: Varroidae) in temperate climates of Argentina, Apidologie 23 (1992) 57-60.

[21] Martin S., Reproduction of Varroa jacobsoni in cells of Apis mellifera containing one or more mother mites and the distribution of these cells, J. Apic. Res. 34 (1995) 187-196.

[22] Martin S., A population model for the ectoparasitic mite Varroa jacobsoni in honeybee (Apis mellifera) colonies, Ecol. Model. 109 (1998) 267-2811. 
[23] Montgomery D.C., Peck E., Introduction to Linear Regression Analysis, John Wiley \& Sons, New York, 1982.

[24] Moritz R.F.A., Mautz D., Development of Varroa jacobsoni in colonies of Apis mellifera capensis and Apis mellifera carnica, Apidologic 21 (1990) 53-58.

[25] Omholt S.W., Crailsheim K., The possible prediction of the degree of infestation of honcybee colonies (Apis mellifera) by Varroa jacobsoni Oud by means of its natural death-rate: a dynamic model approach, Nor. J. Agric. Sci. 5 (1991) 393-400

[26] Otten C., Reproduction and population dynamics of Varroa jacobsoni Oud. in colonies of Apis mellifera L. of different origin, in: Ritter W. (Ed.), Proceedings of the International Symposium on Recent Research on Bee Pathology, 5-7 September 1990, Ghent, Belgium, Merelbeke. Belgium, 1990, pp. 67-69.

[27] Ritter W.. Leclercq E., Entwicklung der Bienenund Varroamilben-Population in Gebieten mit unterschiedlichen Möglichkeiten der Reinvasion, Tierärztliche Umschau 42 (1987) 548-551.
[28] Ritter W., Michel P., Barthoidi M., Schwendemann A., Development of tolerance to Varroa jacobsoni in bee colonies in Tunesia, in: Ritter W. (Ed.), Proceedings of the International Symposium on Recent Research on Bee Pathology, 5-7 September 1990, Ghent, Belgium, Merelbeke, Belgium, 1990, pp. 54-59

[29] Rutiner F., Biogeography and Taxonomy of Honeybees, Springer-Verlag, Berlin, 1988.

[30] Ruttner F., Hänel H., Active defense against Varroa mites in a Carniolan strain of honeybee (Apis mellifera carnica Pollmann), Apidologie 23 (1992) 173-187.

[31] Sakofski F., Koeniger N., Seasonality of honeybec colony invasion by Varroa jacobsoni Oud. Apidologie 21 (1990) 547-550.

[32] Schulz A.E., Reproduktion und Populationsentwicklung der parasitischen milbe Varroa jacobsoni Oud. in Abhängigkeit vom Brutzyklus ihres Wirtes Apis mellifera L, Apidologie 15 (1984) $401-420$.

[33] Thrybom B., Fries I., Development of infestations by Varroa jacobsoni in hybrid colonies of Apis mellifera monticola and Apis mellifera ligustica, J. Apic. Res. 30 (1991) 151-155. 